\title{
The importance of school and academic context in educational performance in a sample of Portuguese adolescents
}

\author{
Leonor Pestana ${ }^{\mathrm{a}}$, João Duarte ${ }^{\mathrm{b}}$, Emília Coutinho ${ }^{\mathrm{b} *}$ \\ * Corresponding author: Emília Coutinho, ecoutinhoessv@gmail.com \\ ${ }^{a}$ Superior Health School, Polytechnic Institute of Viseu, Rua D. João Crisóstomo Gomes de Almeida, $n^{\circ}$ 102, 3500-843 Viseu, \\ Portugal,ecoutinhoessv@gmail.com \\ ${ }^{b}$ Basic School 2/3rd cycle of Viso, Rua da Escola Básica,3505-634, Viseu, Portugal
}

\begin{abstract}
http://dx.doi.org/10.15405/epsbs.2016.07.02.20

The school/academic context is key in engaging students in the learning process and consequently on school performance. Which academic and school context variables influence school performance (study environment, study planning, study method, reading skills, motivation to study, overall school performance) in adolescent? To assess the association between variables - school success, school environment, academic - and school performance in Portuguese adolescents from a sample of the central region. A quantitative, cross sectional, correlational study. Data collected through questionnaire of direct administration (sociodemographic, academic and school context variables and school performance scale). Non-probabilistic convenience sample of 380 students of 7 th, 8th and 9th years of education in the school year 2011/2012, from a 2nd and 3rd cycle Basic School of Viseu Municipality, Portugal. Teens who have never failed $(\mathrm{p}<0.001)$, who live closer to school $(\mathrm{p}=0.007)$ and who spend less time traveling to school $(\mathrm{p}=0.007)$ are those who have a better overall school performance. A better school performance is also achieved, in the study planning $(\mathrm{p}=0.015)$ dimension, by the adolescents with fewer years of schooling. Academic and school context variables, like the grade attended by adolescents, the distance they live from the school, and the time taken in traveling to school, are determinants of adolescent school performance.
\end{abstract}

(C) 2016 Published by Future Academy www.FutureAcademy.org.uk

Keywords: School performance, adolescence, academic variables, school success.

\section{Introduction}

School and academic context are not isolated from other influences experienced by students. Gonzalez-Pienda (2003) points out that not only school performance but also the teenager's personality construction is influenced by his personal life story in their family and social, cultural and relational 
contexts, determining individual and social skills. This author states that school performance conditions include a set of personal and contextual factors (socio environmental, institutional and instructional). Considers that the personal variables include the student characteristics as an apprentice as intelligence, attitudes, learning styles, prior knowledge, gender, age and motivational variables (self-concept, learning goals, causal attributions ...); and the socio-environmental variables refer to social family and economic status, happening in specific linguistic and cultural environment within the youngster is growing. Institutional variables, according to this author, refer to the school as an educational institution and include school organization factors, direction, teachers' education and training, assistants, working environment perceived by the participants in the educational community. The education-related variables include the academic or educational content, teaching methods, practices and homework, the expectations of teachers and students (Gonzalez-Pienda, 2003).

Regarding the study environment / school context, Estanqueiro (2008), states that effective time management requires a fixed place of study, environmentally sound, a quiet, tidy and comfortable place. A moderate temperature, fresh air and good lighting (preferably natural light) and, where appropriate, with a lamp to provide constant light on what one reads or writes, are considered elements of comfort. For a correct body posture is advisable a spacious work desk and a firm chair, suitable for the height of the student. Cosme and Trindade (2002) agree that the environment and the conditions of the place of study are essential for effective time management, with the underlying conditions of the contexts that may optimize or negatively influence the study, and the way to act on these conditions in order to make the study more effective.

One must acknowledge that in terms of the study planning, it is natural and healthy for a young student to occupy part of his time with music, sport, socializing or other social activities, but, like in the opinion of Estanqueiro (2008) time management is necessary, in accordance with a scale of priorities, and that the periods reserved for the individual study should be longer in days of fewer classes. Cosme and Trindade (2002) also argue that the activities and materials related to the study planning aimed at creating the necessary conditions for the student to be organized, taking into account: the difficulties experienced due to the matter or discipline to study; its own characteristics as a person and as a student, the time available to do so, the priorities resulting from the school calendar and the resources available.

Gonzalez-Pienda (2003) showed that the effectiveness of learning is not limited to the cognitive ability, it is also related to the learning styles adopted by the student. These are the different ways that students understand, structure, memorize, learn, and solve tasks and school problems, influencing academic achievement. The author believes that knowing how to use appropriate learning strategies, planning and controlling consciously what one does, can increase the effectiveness of productivity. The student must carry out a self-assessment after studying and before doing exams, and the self-assessment is the test that every student makes himself, to check their level of knowledge and guide their work, through processes that include schematics construction and summaries, problem solving, conducting training tests and preparation of questions and answers. Cosme and Trindade (2002) reported the completion of schematics from texts as one of the activities that promote study success, the preparation of summaries and learning to take notes. A good summary is characterised for brevity, clarity, rigor and personal language. Cosme and Trindade (2002) refer to the development of reading skills, especially those that allow students to address 
http://dx.doi.org/10.15405/epsbs.2016.07.02.20

eISSN: 2357-1330 / Corresponding Author: Emilia Coutinho

Selection and peer-review under responsibility of the Organizing Committee of the conference

strategically targeted a text, analysing and questioning it in order to subsequently be able to paraphrase, systematise, and summarize it, fundamental operations when you want someone to learn to study as a means of learning to learn.

Studies by Carvalho (2012) showed that students with better study habits also presented better school results, being enhanced by the study at home. In this context, the studies of Carrascal \& Rotela (2009) revealed that the family as the first educational institution with specific dynamics has the capacity to interfere with the learning and development of its members and thus directly or indirectly in their academic results. These authors concluded that there are families who are unable to boost the educational process; their educational practices, resources, habits, time and responsibilities are limited, representing an obstacle to the success and learning of their children.

According to Cano-Sánchez-Serrano (2001) academic achievement depends on a number of factors, and among them the psychological factors, sustained in personal determinants such as intelligence and attitudes. These show various capacities of both mental and psychomotor nature and are lifelong developed, through various learning experiences (Cano-Sanchez-Serrano 2001). Jensen (2002) argues that students who go to school every day demonstrate motivation. Causes of demotivation can be inadequate learning styles, lack of resources, language barriers, lack of options, cultural taboos, fear of embarrassment, lack of feedback, malnutrition, prejudices, lack of respect, poor lighting, poor sitting position, wrong temperature, fear of failure and irrelevant content. The motivation depends largely on the context, so it is advantageous the recognition of student success, positive signs, positive non-verbal signals, emotions management of students with drama, movement and celebrations. Estanqueiro (2008) refers to stimuli that could feed the inner strength (intrinsic motivation) of the student, that being dependent on incentives from educators (extrinsic motivation), end when there are no more stimuli. In addition to personality traits and motivation other factors interfere with school performance, such as self-concept, the ability to communicate, the joy in learning. The self-concept involves three different dimensions of the person: the self-image - the vision that one has of itself; the social image - perception of what people think of you, and the ideal image as a projection of what would you would like to be in the ideal plan. In this configuration, the academic performance seems to depend not only on the actual capacity of the person, but also on the capabilities that they believe they have (Cano-Sánchez-Serrano, 2001).

\section{Research Methods}

This study falls within the scope of empirical investigations, following the characteristics of quantitative models, a non-experimental study, cross-sectional, descriptive and correlational, explanatory and retrospective. A total of 380 adolescents $(50.7 \%$ female), from the 7 th to 9 th grade, aged between 11 and 17 years of Viseu Municipality. The percentage of students who live in areas between 1 and $4 \mathrm{~km}$ distant to the school (33.4\%) is equal to those who are distant more than $4 \mathrm{~km}$ and similar to those less than $1 \mathrm{~km}(33.2 \%)$ apart. Most (66.1\%) takes less than 15 minutes from home to school and $10 \%$ goes beyond 30 minutes. A self-report questionnaire was used as data collection instrument on the biographical data, educational and academic context (school year, school performance, distance to school, school travel time), lifestyles (adapted from the European 
questionnaire - the Health Behaviour in School Age Children), sleep habits and the Fermin scale adapted by Duarte (2008) - on school performance. The school performance scale analyses various dimensions of adolescent school activity, including the study environment, the study planning, the study method, reading skills and motivation for study, which together will provide the overall index school performance. The statistical analysis was processed using SPSS (Statistical Package for Social Sciences) version 21.0 for Windows. We used descriptive and inferential statistics. For the inferential statistical parametric and non-parametric tests were used (alternatively) when the parametric test application conditions namely homogenous variances between the groups was not found.

\section{Findings}

School and academic context variables showed 124 students $(32.6 \%)$ are in the $9^{\text {th }}$ grade, 138 students $(36.3 \%)$ in the $8^{\text {th }}$ year, $118(31.1 \%)$ in the $7^{\text {th }}$ year; more than half considered to have average school performance $(62.8 \%)$ and $64.3 \%$ of girls reported an above average performance.

Regarding the characterization of school performance is observed that on average students are more concerned with the study environment $(32.4 \pm 8.21)$ and less with the study planning $(28.27 \pm 15.08)$ with significant differences between gender for all dimensions of school performance (table 1). If given the opportunity to change their schedule, $73.1 \%$ of young people would make this change and $63.7 \%$ would put classes only in the morning.

Table 1. School performance in adolescents

\begin{tabular}{|c|c|c|c|c|c|c|c|c|}
\hline \multirow{2}{*}{ School performance } & \multirow{2}{*}{ Average } & \multirow{2}{*}{ S. D. } & \multicolumn{2}{|c|}{ Male } & \multicolumn{2}{|c|}{ Female } & \multirow{2}{*}{$\mathrm{t}$} & \multirow{2}{*}{$\mathrm{p}$} \\
\hline & & & Average & SD & Average & $\mathrm{SD}$ & & \\
\hline Study Environment & 32.36 & 8.21 & 34.30 & 6.66 & 30.36 & 9.14 & 4.824 & 0.000 \\
\hline Study Planning & 28.27 & 8.15 & 29.54 & 7.18 & 26.96 & 8.88 & 3.116 & 0.002 \\
\hline Study Method & 28.55 & 8.60 & 30.18 & 7.54 & 26.87 & 9.30 & 3.807 & 0.000 \\
\hline Reading Skills & 28.30 & 8.52 & 29.51 & 8.99 & 27.00 & 9.13 & 2.708 & 0.007 \\
\hline Motivation to study & 28.42 & 8.09 & 29.94 & 8.90 & 27.48 & 9.04 & 2.678 & 0.008 \\
\hline $\begin{array}{l}\text { Overall School } \\
\text { Performance }\end{array}$ & 146.69 & 38.31 & 153.74 & 34.43 & 138.67 & 42.77 & 3.775 & 0.000 \\
\hline
\end{tabular}

Considering the year of education and school performance a variance analysis was performed, and results showed that the teenagers who attended the 7th grade, showed better school performance. On the opposite sphere, the teens who attended the 9th grade presented the lower averages. However, the differences are not significant among the three groups, only for study planning ( $\mathrm{p}=0.015)$ (Table 2 ). In fact, these results are consistent with those obtained school performance was associated with age, in which the younger students had better academic performance.

Table 2. School performance and year of education.

\begin{tabular}{|c|c|c|c|c|c|c|c|c|c|c|c|c|}
\hline \multirow{2}{*}{$\begin{array}{l}\text { Year of education } \\
\text { School performance }\end{array}$} & \multicolumn{2}{|c|}{$7^{\text {th }}$} & \multirow{2}{*}{$\begin{array}{c}8^{\text {th }} \\
\text { Average } \\
\end{array}$} & \multirow[b]{2}{*}{$\mathrm{Dp}$} & & \multirow[b]{2}{*}{$\mathrm{F}$} & \multirow[b]{2}{*}{$\mathrm{p}$} & \multirow[b]{2}{*}{$\%$ ve } & \multicolumn{3}{|c|}{ Post Hoc } \\
\hline & Average & $\mathrm{SD}$ & & & Average & $D p$ & & & & $1 \times 2$ & $1 \times 3$ & $2 \times 3$ \\
\hline Study Environment & 33.38 & 8.26 & 32.26 & 9.27 & 31.87 & 8.33 & 0.992 & 0.372 & 0.52 & - & - & - \\
\hline Study Planning & 30.01 & 8.44 & 27.83 & 7.71 & 27.11 & 8.15 & 4.223 & 0.015 & 2.19 & - & 0.015 & - \\
\hline Study Method & 29.74 & 9.32 & 28.45 & 7.97 & 27.53 & 8.51 & 2.024 & 0.134 & 1.06 & - & - & - \\
\hline Reading Skills & 29.59 & 9.38 & 28.23 & 9.62 & 27.07 & 8.19 & 2.318 & 0.100 & 1.21 & - & - & - \\
\hline Motivation to study & 30.14 & 9.40 & 28.57 & 9.27 & 27.57 & 8.30 & 2.495 & 0.084 & 1.30 & - & - & - \\
\hline Overall School & 152.88 & 41.96 & 145.36 & 37.93 & 141.16 & 38.02 & 2.760 & 0.065 & 1.44 & - & - & - \\
\hline
\end{tabular}


Table 3 shows the connection between the school performance of adolescents and school success. The results obtained clearly show that students who have never flunked have better school performance in all dimensions with statistical differences. Not assuming equal variances for the study environment, study planning and overall school performance, the differences are statistically significant, which shows the relationship of dependency between the variables in question.

Table 3. School performance and school success.

\begin{tabular}{lccccccc}
\hline \multicolumn{1}{c}{ School success } & $\begin{array}{c}\text { No fails } \\
\text { Average }\end{array}$ & SD & $\begin{array}{c}\text { With fails } \\
\text { Average }\end{array}$ & SD & Levene's & t & p \\
\hline School performance & 33.71 & 7.77 & 29.22 & 10.01 & 0.000 & 4.133 & 0.000 \\
Study Environment & 29.15 & 7.52 & 25.94 & 9.28 & 0.007 & 3.161 & 0.002 \\
Study Planning & 29.96 & 7.98 & 24.82 & 9.11 & 0.234 & 5.370 & 0.000 \\
Study Method & 29.51 & 8.84 & 25.00 & 9.14 & 0.465 & 4.383 & 0.000 \\
Reading Skills & 29.97 & 8.79 & 25.43 & 8.92 & 0.603 & 4.474 & 0.000 \\
Motivation to study & 152.32 & 35.94 & 130.43 & 43.84 & 0.016 & 4.548 & 0.000 \\
Overall School Performance & & & & & &
\end{tabular}

The time spent traveling can influence the school performance, reduce study time, and lead to greater physical fatigue. In this perspective, a one factor variance analysis was performed and results are presented in Table 4; It is clear that teenagers who are distant up to $1 \mathrm{~km}$ from the school are the ones who generally have better school performance, except for the motivation for the study (higher average in who live between 1 and $4 \mathrm{Km}$ ) and the study planning (higher mean for those school extend more than $4 \mathrm{~km}$ ). Differences between groups were statistically significant for all dimensions between those who live within $1 \mathrm{~km}$ and more than $4 \mathrm{~km}$ and between them and those who live between 1 to 4 $\mathrm{km}$, as results of Tukey post hoc test confirm.

Table 4. School performance and School distance.

\begin{tabular}{|c|c|c|c|c|c|c|c|c|c|c|c|c|}
\hline \multirow[b]{2}{*}{ School performance } & \multicolumn{2}{|c|}{$<1 \mathrm{~km}$} & \multicolumn{2}{|c|}{$1.4 \mathrm{~km}$} & \multicolumn{2}{|c|}{$>=4 \mathrm{~km}$} & \multirow[t]{2}{*}{$\bar{F}$} & \multirow[t]{2}{*}{$\mathrm{p}$} & \multirow[t]{2}{*}{$\%$ ve } & \multicolumn{3}{|c|}{ Post hoc } \\
\hline & Média & $\mathrm{Dp}$ & Média & $\mathrm{Dp}$ & Média & $\mathrm{Dp}$ & & & & 1vs2 & $1 \mathrm{vs} 3$ & $2 v s 3$ \\
\hline Study Environment & 34,16 & 7,78 & 32,93 & 7,74 & 30,37 & 9,91 & 6,508 & 0,002 & 3,33 & - & 0,001 & 0,045 \\
\hline Study Planning & 29,37 & 6,90 & 28,92 & 8,08 & 29,54 & 9,10 & 4,484 & 0,012 & 2,32 & - & 0,016 & 0,051 \\
\hline Study Method & 30,12 & 7,23 & 29,19 & 8,02 & 26,35 & 9,93 & 6,808 & 0,001 & 3,48 & - & 0,001 & 0,021 \\
\hline Reading Skills & 29,69 & 7,15 & 29,31 & 9,61 & 25,84 & 9,93 & 7,052 & 0,001 & 3,60 & - & 0,002 & 0,006 \\
\hline Motivation to study & 29,65 & 7,07 & 30,02 & 9,51 & 26,53 & 9,93 & 5,830 & 0,003 & 2,99 & - & 0,016 & 0,006 \\
\hline $\begin{array}{l}\text { Overall School } \\
\text { Performance }\end{array}$ & 153,00 & 31,38 & 150,39 & 37,91 & 135,64 & 45,69 & 7,380 & 0,001 & 3,76 & - & 0,001 & 0,007 \\
\hline
\end{tabular}

Sometimes the distance between home and school is not proportional to the school travel time and vice versa. By analysing the table, we found that those who spend less time travelling to school have better school performance, while, at the other end, are teens who spend more time ( $\geq 30 \mathrm{~min}$.). The $\mathrm{p}$ value found statistical significance and the post-hoc test Tukey made with the means of ordinances point to differences between those who spend on average up to 15 minutes and 15 to 30 minutes for all dimensions of the scale, and between 15 to $30 \geq$ minutes and 30 minutes for the study environment and study planning. 
Table 5. School performance and travel time to school.

\begin{tabular}{|c|c|c|c|c|c|c|c|c|}
\hline \multirow{2}{*}{$\begin{array}{l}\text { Travel time to school } \\
\text { School per }\end{array}$} & \multirow{2}{*}{$\begin{array}{l}\text { Up to } 15 \mathrm{~min} \\
\text { Average ord }\end{array}$} & \multirow{2}{*}{$\begin{array}{l}15-30 \mathrm{~min} \\
\text { Average ord }\end{array}$} & \multirow{2}{*}{$\begin{array}{l}\geq 30 \mathrm{~min} \\
\text { average ord }\end{array}$} & \multirow{2}{*}{$\mathrm{X} 2$} & \multirow{2}{*}{$\mathrm{p}$} & \multicolumn{3}{|c|}{ Post hoc } \\
\hline & & & & & & $1 \mathrm{vs} 2$ & $1 \mathrm{vs} 2$ & $2 v s 3$ \\
\hline Study Environment & 200,52 & 192,08 & 120,53 & 17,69 & 0,000 & --- & 0,000 & 0,002 \\
\hline Study Planning & 199,59 & 189,38 & 133,12 & 12,13 & 0,002 & --- & 0,001 & 0,020 \\
\hline Study Method & 200,72 & 180,69 & 146,46 & 9,051 & 0,011 & --- & 0,012 & --- \\
\hline Reading Skills & 198,86 & 182,73 & 153,86 & 6,184 & 0,045 & --- & 0,047 & --- \\
\hline Motivation to study & 199,13 & 182,25 & 153,22 & 6,497 & 0,039 & --- & 0,042 & --- \\
\hline Overall School & & & & & & & & \\
\hline Performance & 199,70 & 186,04 & 140,42 & 9,812 & 0,007 & --- & --- & --- \\
\hline
\end{tabular}

\section{Discussion}

The statistics relating to school context and academic variables (school year, school performance, distance to school, school travel time) allow inferring that adolescents in all subscales related to age, sex and grade, have an above average productivity getting the highest rate in the study environment and the lowest in the study planning, with statistical significance between groups and in relation to the school year. More than half of students $(53.8 \%)$ already failed once in their school career, with higher prevalence in girls. Corroborating the current study, Duarte (2008) presents a study in which girls show better academic performance in all subscales compared with boys. It showed that these findings are contrary to the Directorate of Planning and Cooperation of the Ministry of Education, 2006 by stating that the academic performance of secondary school students is higher in males (Duarte 2008). In other European countries, the research carried out by a team coordinated by Balaguer (2002), about the lifestyles of adolescents aged 11,13 and 15 in the Valencian community used a similar sample to the present, with adolescents with a mean age of 13.14 years, with a similar distribution by sex and, likewise, dealing with the psychosocial determinants of lifestyles related to health in adolescents. It was evident in our study that students who never failed showed better school performance, same result as Olvera \& Moya (2012). In this research, and in relation to school performance, students who never failed have a better school performance in all dimensions in the study, a statistically significant difference, which shows the relationship of dependency between variables. Academic achievement is higher in that cramped conditions up to $1 \mathrm{~km}$ and take less time traveling to school which is corroborated with the data obtained by other researchers as Seabra, Mendonça, Thomis, Anjos, Maia (2008); Morales- Serrano et al. (1999) Mascarenhas, Almeida, \& Barca (2005), Navarro (2003).

As for the distance from the place of residence and travel time to school, the inhabitants living up to $1 \mathrm{~km}$ from the school are the ones who have better academic performance, except for the motivation for study and the study planning, which is registered in those who live at a distance from 1 to $4 \mathrm{~km}$ and above this range respectively. Also those who spend less time on travel to school, present a better school performance. The relationship between school performance and contextual variables to school and academic, found that 7 th graders had better school performance, and the lower productivity is with the 9th graders, but the differences between the three study groups are just in the study planning of the These results go against those obtained when we related school performance with age, in which the younger had better academic performance. With similar results, Pastor, Valcárcel, and García-Merita (2002) with teenagers aged between 11 and 16 years, studied the degree of satisfaction with the school 
experience, academic performance perceived by students, time investing to achieve the homework and the adolescents future plans, concluding that with regard to the perceived school performance, most young people are satisfied with the achieved yield. About three-quarters of the youngsters perceive globally that they have an productivity below average and $16 \%$ of boys think it's very good school performance. A high percentage of boys perceive their school performance as average $(38 \%)$ or good (39\%). Globally younger students value your academic performance than those who study at more senior levels. In the case of girls, $44 \%$ are considering that your yield is good, $35 \%$ considered medium and $15 \%$ considered very good. Few girls to consider having a school performance below average and the same as it was found in boys the younger girls are who perceive more positive school performance compared to the older ones

\section{Conclusions}

We sought to identify the variables of school and academic context, with an emphasis on study habits that are predictors of academic performance of adolescents. We assessed that the grade the student is on influence school performance in relation to the planning of the study. School failure, the distance from home to school and travel time are predictors of academic performance in its different dimensions.

The approach was with the underlying socio-demographic factors (gender, age), related to the school year, proved that girls and younger students ( $\leq 12$ years) show better academic performance in all dimensions of scale and overall value. They also have better school performance, the ever rejected, that are distant than $1 \mathrm{~km}$ from school and spend less time traveling between home and school.

\section{Acknowledgements}

The Portuguese Foundation for Science and Technology (FCT), the Centre for Studies in Education, Technologies and Health (CI\&DETS) and Odete Amaral for text revision.

\section{References}

Balaguer, I., Castillo, I., Pastor, Y., Moreno, Y., \& Atienza, F. L. (2002). La investigación sobre los estilos de vida de los adolescentes de 11, 13 y 15 años de la Comunidad Valenciana. In I. Balaguer (Ed.), Estilos de vida en la adolescencia (pp. 27-36). Valencia: Promolibro.

Cano-Sánchez-Serrano, J. (2001). Rendimiento escolar y sus contextos. Revista Complutense de Educación, 12(1), $15-80$.

Carrascal, R. E. E., \& Rotela, M. M. (2009). Influencia de la Familia en el Proceso Educativo de los Menores del Barrio Costa Azul de Sincelejo (Colombia). Investigación \& Desarrollo, 17(1). Retrieved from http://rcientificas.uninorte.edu.co/index.php/investigacion/article/viewArticle/803/4568

Carvalho, P. S. (2012). hábitos de estudo e sua influencia no rendimento escolar. (Master), Universidade Fernando Pessoa, Porto. Retrieved from http://hdl.handle.net/10284/3572

Cosme, A., \& Trindade, R. (2002). Área de Estudo Acompanhado (Asa Ed. 6 ed.).Porto: Asa Editores.

Duarte J. Privação do sono, rendimento escolar e equilíbrio psicoafectivo na adolescência. Porto: Universidade do Porto; 2008.

Estanqueiro, A. (2008). Aprender a Estudar (L. Texto Editores Ed. 13 ed.). Lisboa.

González-Pienda, J. A (2003). El rendimiento escolar. Un análisis de la variables que lo condicionan. Revista Galego-Portuguesa de Psicoloxía e Educación, $\mathrm{n}^{\circ} 7$ - vol. 9, 247-258.

Jensen, E. (2002). O cérebro, a bioquímica e as aprendizagens - Um guia para pais e educadores (ASA Ed. 1 ed.). Porto.

Mascarenhas, S., Almeida, L. S., \& Barca, A. (2005). Atribuições causais e rendimento escolar: Impacto das habilitações escolares dos pais e do género dos alunos. Revista Portuguesa de Educação, 18 (1), 79-91 
eISSN: $2357-1330$

Selection and peer-review under responsibility of the Organizing Committee

Matos, M. G., Simões, C., Tomé, G., Camacho, I., Ferreira, M., Ramiro, L., et al. (2012) A Saúde dos Adolescentes Portugueses. Equipa do Projeto Aventura Social e Saúde em 2010 ed. Saúde ASA, editor. Lisboa: FMH/ Universidade Técnica de Lisboa. 